\title{
EFIKASI DIRI DENGAN KECENDERUNGAN KECANDUAN INTERNET PADA REMAJA DIMASA PANDEMI COVID-19
}

\author{
SELF-EFFICIENCY WITH INTERNET ADDICTION TRENDS IN YOUTH IN THE COVID-19 \\ PANDEMIC
}

Oleh :

\section{Ramadani Anisa Firdaus ${ }^{1}$}

Dinar Sari Eka Dewi ${ }^{2}$

\begin{abstract}
During the COVID-19 pandemic, almost all activities are carried out online which have an impact on the educational aspect. These activities make teenagers spend a lot of time using the internet. This a negative impact on adolescents, tendency to become addicted to the internet. Self-efficacy can act as an individual effort in dealing with the problems faced. The purpose to determine the relationship between self-efficacy and Internet addiction tendencies in adolescents during the Covid-19 pandemic.This research is a quantitative research. The sampling technique used propotionate stratified random sampling. The measuring tools are self-efficacy scale and Internet Addiction Test. There are 154 adolescent subjects. The conclusion is a relationship between self-efficacy and internet addiction tendencies in adolescents with significant and negative results. The analysis of the product moment correlation test, the correlation $r=-0.638$ with $p=0.000(p<0.01)$.
\end{abstract}

Keywords: Self Efficacy; Internet Addiction Tendencies.

\begin{abstract}
ABSTRAK
Di masa pandemi covid-19 hampir seluruh kegiatan dilakukan secara online yang memberi dampak dalam aspek pendidikan. Kegiatan tersebut membuat remaja banyak menghabiskan waktu terus menerus menggunakan internet. Hal ini memberi dampak negatif pada remaja yakni kecenderungann kecanduan internet. Efikasi diri dapat berperan sebagai usaha atau upaya individu dalam menghadapi permasalahan yang sedang dihadapi. Penelitian ini bertujuan untuk mengetahui Hubungan Antara Efikasi Diri dengan Kecanduan Internet pada Remaja di Masa Pandemi Covid-19. Penelitian ini merupakan penelitian kuantitatif. Teknik pengambilan sampel menggunakan propotionate stratified random sampling. Alat ukur yakni skala efikasi diri dan Internet Addiction Test. Subjek remaja berjumlah 154 . Hasil penelitian menunjukkan terdapat hubungan antara efikasi diri dengan kecenderungan kecanduan internet yang negatif signifikan pada remaja. Berdasarkan dari hasil analisis uji korelasi product moment diperoleh korelasi $\mathrm{r}=-0,638$ dengan $\mathrm{p}=0,000(\mathrm{p}<0,01)$.
\end{abstract}

Kata kunci: Efikasi Diri ; Kecenderungan Kecanduan Internet

\section{PENDAHULUAN}

Beberapa tahun ini penyebaran covid-19 yang berasal dari Wuhan, China (Sari dkk., 2020). Dampak dari penyebaran covid-19 memberikan suatu permasalahan muncul pada sektor ekonomi, pemerintahan, pendidikan dan lain sebagainya (Hakim dkk., 2021). Apalagi dimasa sekarang dengan adanya perkembangan waktu dan kemajuan teknologi sekarang (Wita dkk., 2018). Pengguna internet merupakan kegiatan individu yang terhubung dengan internet setiap hari, kapanpun dan dimanapun individu berada (Novianty dkk., 2019). Pertumbuhan pada tahun 2018 hingga 2019-2020 sebesar 73,7\% (APJII, 2020). Pengguna terbanyak pada usia remaja usia 15 hingga 19 tahun dan tingkat pendidikan 90,2 \% pada sekolah menengah atas (APJII, 2018).

\footnotetext{
${ }^{1}$ Ramadani Anisa Firdaus, Universitas Muhammadiyah Purwokerto, dan ramadaniaf80@ gmail.com

${ }^{2}$ Dinar Sari Eka Dewi, Universitas Muhammadiyah Purwokerto, dan dinardewi3@gmail.com
} 
Pemilihan remaja SMK berbasis Informasi Teknologi yang secara langsung penggunaan internet cukup tinggi dan memiliki ketergantungan akan internet untuk belajar maupun untuk aktivitas online lain (Hakim dkk., 2021). Penggunaan internet di rumah memiliki kelemahan karena kurangnya pengawasan dari guru secara langsung untuk mengontrol penggunaan internet selain untuk belajar (Darmawan, 2019). Apalagi di masa pandemi seperti ini banyak individu yang mengisi waktu luangnya untuk melakukan aktivitas secara online (Darmawan, 2019).

Berakibat pada remaja setelah belajar maupun saat pembelajaran online remaja menggunakan internet untuk aktivitas bermain game online, media sosial, nonton dan aktivitas yang berhubungan langsung dengan internet. Berdasarkan hasil survei APJII menunjukkan data penggunaan internet untuk menonton video 45,3\%, bermain game online $17,1 \%$, membuka aplikasi belanja, bermain media sosial (instagram 17,8\%, facebook 50,7\%, youtobe 15,1\%) (APJII, 2017). Remaja menjadi usia yang rentan dalam menggunaan internet dikarenakan masa remaja merupakan masa peralihan dari anak-anak hingga dewasa (Wulandari, 2019).

Awal mulanya kecanduan internet muncul ditandai dengan penggunaan internet yang berlebihan (Irman dkk., 2019). Penggunaan internet secara berlebih menurut DSM-V mencapai 30 jam dalam seminggu atau 4 hingga 5 jam perhari (Mareta dkk., 2020). Menurut Young (1998) kecanduan internet adalah gejala yang ditandai dengan menghabiskan banyak waktu menggunakan internet dan tidak dapat mengendalikan atau mengontrol penggunaan secara online. Kegiatan menggunakan internet secara terus-menerus dalam waktu yang lama dapat memberi efek negatif karena mengalami kecenderungan kecanduan internet (Latief \& Retnowati, 2018).

Demikian dapat menyebabkan remaja memiliki kecenderungan kecanduan internet. Individu yang mengalami kecenderungan kecanduan internet pada umumnya menjadi ketagihan dalam bersosial media, game online, dan menonton video di youtobe (Gustilawati dkk., 2020). Menurut Bandura (dalam Berte dkk., 2019), kecanduan internet sebagai tantangan kontrol diri dan efikasi diri yang dapat mempengaruhi pengguna internet.

Penelitian sebelumnya yang dilakukan oleh Yang \& Kim (2018) Effects Of A Prevention Program For Internet Addiction Among Middle School Students In South Korea menunjukkan bahwa adanya hubungan antara pengendalian diri, efikasi diri, dan kecanduan internet, waktu yang dihabiskan di internet. Serta penelitian dari Guiseppe Craparo, Roberta Messina, Sergio Saverino, Silvia Fasciano, Vicenza Cannella, Alessio Gori, Marco Cacioppo, Roberto Baiocco (2014) The Relationships Between Self-Efficacy, Internet Addiction And Same menunjukkan adanya hubungan yang signifikan.

Adanya efikasi diri dapat mempengaruhi peran yang dilakukan individu secara sosial, dan dalam menghadapi persoalan tertentu. Bandura (1997) mengatakan bahwa self-efficacy merupakan hasil dari proses kognitif berupa keputusan, keyakinan, atau penghargaan tentang sejauh mana individu memberikan kemampuan dirinya dalam melaksanakan tindakan tertentu yang diperlukan untuk mencapai hasil yang diinginkan atau di harapkan (Gustilawati et al., 2020). Melalui efikasi diri yang dimiliki remaja dapat membuat remaja mampu untuk menghadapi berbagai situasi (Permana dkk., 2016).

Pada akhirnya remaja memiliki keyakinan mampu menggunakan teknologi informasi baru sesuai dengan kebutuhan (Kim \& Glassman, 2013). Berdasarkan hasil survei terhadap sembilan remaja, ditemukan alasan menggunakan internet di masa pandemi ini pada remaja digunakan untuk mengisi waktu senggang atau luang, menghilangkan kebosanan, bermain game online, untuk menghibur diri, bermain sosial media, dan membantu dalam mengerjakan tugas. Adapun yang membutuhkan internet untuk mempermudah dirinya dan agar tidak ketinggalan zaman karena perkembangan teknologi yang semakin maju. 
Subjek menghabiskan waktu menggunakan internet enam jam hingga diatas delapan jam. Serta subjek setiap hari menggunakan internet karena mereka tidak dapat lepas dari internet. Ketika subjek terganggu saat melakukan aktivitas yang berhubungan dengan internet, subjek bereaksi jadi tidak mood, dan marah. Apalagi dimasa pandemi ini banyak waktu luang yang dapat digunakan remaja untuk melakukan aktivitas online. Banyak remaja yang menggunakan internet diatas delapan jam sehingga merasakan kenyamanan saat menggunakan internet.

Dari latar belakang diatas, maka dapat diperkirakan bahwa remaja yang memiliki efikasi diri yang rendah pada remaja dapat menimbulkan kecenderungan kecanduan internet. Berdasarkan hal tersebut, rumusan masalah dalam penelitian ini adalah "apakah ada hubungan antara efikasi diri dengan kecenderungan kecanduan internet pada remaja di masa pandemi Covid-19 di SMK X Purwokerto?'. Tujuan penelitian adalah untuk mengetahui hubungan antara efikasi diri dengan kecenderungan kecanduan internet pada remaja di masa pandemi covid-19 di SMK X Purwokerto.

\section{TINJAUAN PUSTAKA}

\section{Kecenderungan Kecanduan Internet}

Kecenderungan merupakan tendensi untuk mengalami gangguan dalam penggunaan internet yang bersifat patologis. Menurut Young (1998) kecanduan internet adalah gejala yang ditandai dengan menghabiskan banyak waktu menggunakan internet dan tidak dapat mengendalikan atau mengontrol penggunaan secara online. Griffith (2003) mengatakan bahwa kecanduan internet adalah perilaku adiktif yang meliputi interaksi antar manusia tanpa menggunakan obat-obatan.

Mustafa (2011) berpendapat bahwa, kecanduan internet merupakan kontrol keinginan dalam diri individu yang menyebabkan pengguna mengalami ketagihan dan sulit berhenti. Kecanduan internet merupakan sesuatu yang ditandai dengan keinginan yang kuat untuk mengakses jejaring internet, menghabiskan waktu menggunakan internet untuk kepuasan (Azizah dkk., 2019).

Kecenderungan kecanduan internet adalah tendensi suatu gejala yang ditandai dengan menghabiskan waktu menggunakan internet, sulitnya mengontrol penggunaan internet dan sulitnya berhenti menggunakan internet, yang ditimbulkan tanpa adanya penggunaan obat-obatan. Adapun menurut aspek-aspek kecanduan internet antara lain yakni:

a. Salience adalah suatu kegiatan ataupun aktivitas yang biasa menjadi kegiatan atau aktivitas yang penting dalam kehidupan individu tersebut

b. Mood adalah suatu pengalaman individu tentang perubahan emosi yang dipengaruhi oleh kegiatan tersebut (menggunakan internet).

c. Toleransi adalah proses peningkatan waktu menggunakan internet untuk sampai mencapai sensasi yang diinginkan individu tersebut.

d. Withdrawal adalah dimama perasaan dan sensasi yang tidak nyaman atau menyenangkan ketika aktivitas menggunakan internet tiba-tiba berhenti atau tidak dilanjutkan kembali.

e. Konflik adalah mengarahkan pada pengguna internet akan permasalahan interpersonal ataupun intrapersonal.

f. Relapse adalah merupakan suatu dimana keadaan individu memiliki kecenderungan untuk kembali lagi kepada perilaku menggunakan internet yang berlebihan.

Menurut Mark Griffith (dalam Young \& Abreu, 2017) faktor yang mempengaruhi kecanduan internet antara lain: 
a. Kenyamanan adalah kenyamanan individu saat melakukan aktivitas online yang tidak mengharuskan individu keluar rumah sehingga individu nyaman saat menggunakan internet di tempat yang membuatnya nyaman.

b. Pelarian adalah mengarahkan individu untuk lari dari masalah kehidupan yang nyata, seperti stress dan tegang menghadapi masalah.

c. Aksesibilitas adalah dimana akses menggunakan internet pada era sekarang mudah digunakan dimana saja dan tersebar luas dimana saja.

d. Terjangkau adalah murah dan mudah men-download layanan internet bahkan gratis untuk men-download aplikasi sehingga tidak mengeluarkan uang.

e. Tidak adanya hambatan adalah penggunaan internet yang mudah dan cepat tanpa ada hambatan ataupun halangan sehingga membuat individu tidak ragu menggunakan internet dan individu juga dapat membuka diri individu melalui aplikasi yang sudah disedikan internet.

\section{Efikasi Diri}

Dalam teori sosial kognitif yang dikenalkan oleh Bandura (Bandura, 1995), dikenal dengan istilah efikasi diri yang dapat mempengaruhi aktivitas, usaha seseorang dalam menyelesaikan permasalahan yang dihadapi. Efikasi diri yang mengacu pada pemikiran individu sendiri mengenai kemampuan dalam situasi tertentu. Bandura (1997) mengatakan bahwa efikasi diri yakni hasil dari serangkaian proses kognitif dalam bentuk keputusan, keyakinan, ataupun penghargaan mengenai kemampuan dirinya dalam bertindak untuk mencapai hasil yang diinginkan.

Alwisol (2009) mengatakan bahwa self-eficaccy merupakan sebagai persepsi individu mengenai keyakinan diri bahwa individu memiliki kemampuan melakukan tindakan sesuai yang diharapkan. Menurut Feist \& Feist (dalam Triyono \& Rifai, 2018), efikasi diri merupakan keyakinan individu terhadap kemampuan yang ada, pada dirinya yang dijadikan dasar dalam melaksanakan suatu kegiatan untuk mencapai hasil tertentu.

Dapat disimpulkan bahwa efikasi diri merupakan keyakinan individu terhadap kemampuan yang ada di dalam diri individu sendiri dalam menghadapi masalah untuk mencapai tujuan atau hasil yang diinginkan oleh individu tersebut dan dapat mengatasi hambatan yang ada. Menurut Bandura (Ghufron \& Suminta, 2010) dimensi efikasi diri antara lain:

a. Dimensi tingkat (level) adalah berkaitan dengan tingkat kesukaran persoalan atau permasalahan ketika individu merasa mampu untuk melakukan.

b. Dimensi kekuatan (strength) adalah berkaitan dengan tingkat kekuatan keyakinan atau harapan seseorang mengenai kemampuannya. Keyakinan yang kuat akan mendorong individu tetap bertahan akan usahanya. Namun, keyakinan yang lemah akan mudah goyah oleh pengalaman yang kurang mendukung.

c. Dimensi generalisasi (generality) adalah berkaitan dengan luas bidang tingkah laku dimana individu merasa yakin akan kemampuan yang dimiliki dirinya.

Menurut Bandura (Ghufron \& Suminta, 2010) faktor yang mempengaruhi efikasi diri antara lain:

a. Perfomansi keberhasilan (mastery ecperience) adalah Pengalaman keberhasilan sumber yang dapat mempengaruhi efikasi diri individu karena berdasarkan pengalaman yang benar-benar nyata.

b. Pengalaman orang lain (vicarious experience) adalah Mengamati keberhasilan orang lain dengan kemampuan yang sebanding dalam menyelesaikan suatu permasalahan akan meningkatkan efikasi seseorang dalam bertindak. 
c. Persuasi verbal (verbal persuasion) adalah Individu akan diarahkan dengan bimbingan, saran, dan nasehat, sehingga dapat meningkatkan keyakinan akan kemampuan yang dimiliki individu untuk mencapai tujuan yang diinginkan.

d. Kondisi fisik dan emosional (physiological and emotional state) adalah aktivitas yang melibatkan kekuatan dan daya tahan, individu mengartikan kelelahan dan rasa sakit yang dirasakan sebagai tanda mengenai efikasi diri.

\section{Remaja}

Masa remaja merupakan masa transisi dan kelanjutan dari masa anak-anak menuju tingkatan untuk mencapai kedewasaan. Proses transisi remaja ditandai dengan berbagai perubahan seperti fisik, mental, intelektual dan juga sosial (Wulandari, 2019). Menurut Papalia dan Old mengatakan bahwa masa remaja merupakan masa transisi antara dari masa kanak-kanak sampai masa dewasa yang dimulai pada usia 12 atau 13 tahun dan berakhir pada usia awal usia dua puluh tahun (Putro, 2017). Remaja adalah masa kritis peralihan dari anak menjadi dewasa (Jannah, 2016).

\section{METODE PENELITIAN}

\section{Penelitian Kuantitatif}

Variabel yang digunakan dalam penelitian ini adalah efikasi diri dan kecenderungan kecanduan internet. Pendekatan penelitian yang digunakan yakni kuantitatif. Teknik analisis yang digunakan ialah koreasi produck moment dari Carl Pearson. Tujuan untuk mengetahui hubungan antara efikasi diri dengan kecenderungan kecanduan internet. Responden penelitian ialah siswa kelas 10 dan 11 SMK X Purwokerto. Populasi berjumlah 768 remaja. Teknik pengambilan sampel yakni propotionate stratified random sampling. Subjek berjumlah besar maka diambil antara 10\%-20\% atau 20\%-25\% dari populasi (Arikunto, 2013).

Penelitian ini mengambil $20 \%$ dari populasi yang ada $20 \% \times 768=154$ remaja kelas 10 dan 11. Metode pengumpulan data menggunakan skala likert. Kemudian memberikan lima pilihan jawaban yakni sangat setuju (SS), setuju (S), netral (N), tidak setuju (TS), dan sangat tidak setuju (STS). Dengan aitem pernyataan yang mendukung (favorable) dan tidak mendukung (unfavorable). Penelitian ini menggunakan alat ukur Internet Addiction Test (IAT) dan skala efikasi diri. Alat ukur kecanduan internet yang digunakan adalah modivikasi alat ukur Internet Addiction Test (IAT) yang dibuat oleh Kimberly S Young yang dibuat pada tahun 1998 (dalam Young \& Abreu, 2017) secara keseluruhan Internet Addiction Test (IAT) terdiri dari 20 aitem. Skala efikasi diri yang berjumlah 30 aitem. Hasil uji reabilitas menunjukkan koefisien alpa Cronbach efikasi diri sebesar 0,930 dan koefisien alpa Cronbach kecenderungan kecanduan internet 0,827 . Teknik analisis data dilakukan melalui analisis product moment dengan perhitungan data dibantu menggunakan SPSS 20.

\section{HASIL}

Kategorisasi efikasi diri berdasarkan hasil penelitian yakni dari 154 responden memiliki skor efikasi diri yang berbeda. Terdapat 9 responden tergolong sangat tinggi 5,8\%. Terdapat 27 responden tergolong tinggi 17,6\%. Terdapat 69 responden tergolong sedang 44,8\%. Terdapat 48 responden tergolong rendah dengan prosentase 30,5\%. Terdapat 2 responden tergolong sangat rendah $1,3 \%$.

Kategorisasi kecederungan kecanduan internet berdasarkan hasil penelitian yakni dari 154 responden memiliki skor kecederungan kecanduan internet yang berbeda. Terdapat 4 responden tergolong sangat tinggi 2,6\%. Terdapat 35 responden tergolong tinggi $22,7 \%$. Terdapat 65 responden tergolong sedang 42,2. Terdapat 45 responden tergolong rendah $29,2 \%$. Terdapat 5 responden tergolong sangat rendah $3,2 \%$. Jenis kelamin laki-laki lebih banyak 
RAMADANI ANISA FIRDAUS \& DINAR SARI EKA DEWI

Efikasi Diri Dengan Kecenderungan Kecanduan Internet pada Remaja Dimasa Pandemi Covid-19

daripada perempuan yakni 108 laki-laki dan 46 perempuan. Ditinjau dari usia yakni 15 tahun sebanyak 12 orang, 16 tahun sebanyak 78 orang, 17 tahun sebanyak 63 orang serta 18 tahun sebanyak 1 orang.

Tabel 1. Uji Normalitas

\begin{tabular}{clcc}
\hline No & \multicolumn{1}{c}{ Variabel } & P & Keterangan \\
\hline 1 & Efikasi Diri & 0,075 & Normal \\
2 & Kecenderungan Kecanduan Internet & 0,200 & Normal \\
\hline
\end{tabular}

Berdasarkan data diatas, menunjukkan bahwa persebaran data tergolong normal (nilai signifikan $\mathrm{p}>0,05)$. Uji linieritas juga menujukkan bahwa data linier.

Tabel 2. Uji Linearitas

\begin{tabular}{cccc}
\hline Variabel X & Variabel Y & P & Keterangan \\
\hline Efikasi Diri & $\begin{array}{l}\text { Kecenderungan Kecanduan } \\
\text { Internet }\end{array}$ & 0,247 & Linier \\
\hline
\end{tabular}

Berdasarkan dari hasil analisis uji korelasi product moment diperoleh nilai koefisien korelasi $r=-0,638$ dengan $p=0,000(p<0,01)$. Hal ini menunjukkan bahwa terdapat hubungan yang kuat, negatif dan signifikan antara efikasi diri dengan kecenderungan kecanduan internet pada remaja.

\section{PEMBAHASAN}

Hasil uji hipotesis pada variabel efikasi diri dengan kecenderungan kecanduan internet diperoleh nilai koefisien $r=-0,638$ dengan $p=0,000(p<0,01)$. Hal ini menunjukkan bahwa terdapat hubungan yang kuat serta negatif dan signifikan antara efikasi diri dengan kecenderungan kecanduan internet. Artinya semakin tinggi efikasi diri yang dimiliki, maka semakin turun kecenderungan kecanduan internet. Peneltian ini sejalan dengan penelitian sebelumnya tentang effects of a prevention program for internet addiction among middle school students in South Korea (Yang \& Kim, 2018) menunjukkan bahwa adanya hubungan.

Hasil penelitian sebelumnya juga Guiseppe Craparo, dkk (2014) the relationships between self-efficacy, internet addiction and same menunjukkan adanya hubungan yang signifikan. hal yang membedakan penelitian ini dengan penelitian sebelumnya ialah pada negara, dimasa pandemi covid-19, penggunaan alat ukur, dan subjek yang digunakan. Selfefficacy adalah keyakinan pada kemampuan motivasi seseorang, keterampilan kognitif, dan tindakan yang diperlukan untuk mengatasi tuntutan situasi saat ini (Bandura, 1997).

Di masa pandemi, remaja memiliki waktu luang yang cukup untuk bermain game online, nonton video maupun media sosial (Hakim dkk., 2021). Artinya efikasi diri ini mampu menahan dirinya untuk mengurangi mengakses internet terlalu lama di situasi kondisi pandemi ini. Karena isu terkait epidemi ini, jumlah anak muda yang menggunakan internet meningkat, terutama antara usia 15 dan 19 tahun (APJII, 2018). Oleh karena itu dengan adanya efikasi diri ini remaja berusaha dengan kemampuan yang ada untuk mengurangi penggunaan internet.

Hasil penelitian ini menunjukkan berdasarkan jenis kelamin bahwa pengguna internet paling banyak ialah laki-laki daripada perempuan. Hal ini dikarenakan laki-laki cenderung menghabiskan lebih banyak waktunya di internet dibanding dengan perempuan. Laki-laki juga lebih memilih menggunakan waktunya berselancar di dunia maya untuk mencari kesenangan seperti nonton dan bermain game online. Adapun akses dalam untuk mendapatkan internet lebih mudah (Lombogia dkk., 2018). 


\section{KESIMPULAN DAN SARAN}

Kesimpulan dari penelitian ini ialah hipotesis dalam penelitian ini dapat diterima. "Ada hubungan antara efikasi diri dengan kecenderungan kecanduan internet pada remaja di masa pandemi covid-19 di SMK X Purwokerto". Nilai diperoleh nilai koefisien $r=-0,638$ dengan $p$ $=0,000(\mathrm{p}<0,01)$. Hal ini menunjukkan bahwa terdapat hubungan yang negatif dan signifikan serta nilai $r$ menunjukkan hubungan yang kuat.

Saran diberikan kepada Remaja (siswa) untuk mencari informasi mengenai efikasi diri dan dampak dari penggunaan internet. Bagi sekolah memberikan pelatihan terkait efikasi diri dan psikoedukasi mengenai kecenderungan kecanduan internet. Bagi peneliti selanjutnya dapat meneliti faktor yang memepengaruhi kecenderungan kecanduan internet seperti pola asuh, kualitas tidur, malu, prokrastinasi dan kontrol diri.

\section{Daftar Pustaka}

Alwisol. (2009). Psikologi Kepribadian. UMM Pres.

APJII. (2020). Laporan Survei Internet APJII 2019 - 2020. APJII. https://apjii.or.id/survei

APJII. (2017). Penetrasi \& Profil Perilaku Pengguna Internet Indonesia. APJII. https://apjii.or.id/survei2018s/download/TK5oJYBSyd8iqHA2eCh4FsGELm3ubj

APJII. (2018). Penetrasi \& Profil Perilaku Pengguna Internet Indonesia. APJII. https://apjii.or.id/survei2018s/download/TK5oJYBSyd8iqHA2eCh4FsGELm3ubj

Arikunto, S. (2013). Prosedur Penelitian: Suatu Pendekatan Praktik. Rineka Cipta.

Azizah, S. M., Andayani, T. R., \& Scarvanovi, B. W. (2019). Kualitas Relasi Remaja dan Orang Tua dengan Kecanduan Internet pada Siswa Sekolah Menengah Atas Pengguna Smartphone. Jurnal Psikologi Teori Dan Terapan, 9(2), 112-121. https://doi.org/10.26740/jptt.v9n2.p112-121

Bandura, A. (1995). Self-Efficacy In Changing Societies. In 2017 12th International Conference on Ecological Vehicles and Renewable Energies, EVER 2017. Cambridge Univercity Press. https://doi.org/10.1109/EVER.2017.7935960

Bandura, A. (1997). Self-eEficacy: The Exercise Of Control. In Stanford University (pp. 1604).

Stanford

University.

http://search.ebscohost.com/login.aspx?direct=true \&db=a9h\&AN=9703260522\&site=e host-live

Berte, D. Z., Mahamid, F. A., \& Affouneh, S. (2019). Internet Addiction and Perceived SelfEfficacy Among University Students. International Journal of Mental Health and Addiction, 1-15. https://doi.org/10.1007/s11469-019-00160-8

Craparo, G., Messina, R., Severino, S., Fasciano, S., Cannella, V., Gori, A., Cacioppo, M., \& Baiocco, R. (2014). The Relationships Between Self-Efficacy, Internet Addiction and Shame. Indian Journal of Psychological Medicine, 36(3), 304-307. https://doi.org/10.4103/0253-7176.135386

Darmawan, F. H. (2019). Kecanduan Internet Pada Mahasiswa Program Studi Kebidanan (D3) Sebagai Dampak Pembelajaran Jarak Jauh Di Era Pandemi, Mungkinkah? PINLITAMAS I, 2(1), 146-157.

Ghufron, M. N., \& Suminta, R. R. (2010). Teori-Teori Psikologi (R. Kusumaningrati (ed.)). Ar-Ruzz Media.

Griffiths, M. (2003). Internet Gambling: Issues, Concerns, and Recommendations. CyberPsychology \& Behavior, 6(6), 557-568.

Gustilawati, B., Utami, D., \& Farich, A. (2020). Tingkat Kecanduan Smartphone dan Self Efficacy dengan Prestasi Belajar Mahasiswa Fakultas Kedokteran Universitas Malahayati. Jurnal Ilmiah Kesehatan Sandi Husada, 11(1), 109-115. https://doi.org/10.35816/jiskh.v10i2.230 
Hakim, T. D., Vita, A., \& Monika, W. (2021). PKM Penyuluh Internet Sehat di Smk Telkom Pekanbaru. Jurnal Pengabdian Dan Edukasi Sekolah, 1(1), 51-59.

Irman, I., Saari, C. Z., Silvianetri, S., Rajab, K., \& Zalnur, M. (2019). The Effect of Zikir Relaxation in Counseling to Reduce Internet Addiction. Al-Ta Lim Journal, 26(1), 1-11. https://doi.org/10.15548/jt.v26i1.547

Jannah, M. (2016). Remaja Dan Tugas-Tugas Perkembangannya Dalam Islam. Jurnal Psikoislamedia, 1(1), 243-256. https://doi.org/10.22373/psikoislamedia.v1i1.1493

Kim, Y., \& Glassman, M. (2013). Beyond search and communication: Development and validation of the Internet Self-efficacy Scale (ISS). Computers in Human Behavior, 29(4), 1421-1429. https://doi.org/10.1016/j.chb.2013.01.018

Koç, M. (2011). Internet Addiction And Psychopatology. Turkish Online Journal of Educational Technology, 10(1), 143-148.

Latief, N. S. A., \& Retnowati, E. (2018). Kesepian Dan Harga Diri Sebagai Prediksi Dari Kecanduan Internet Pada Reamaja. Jurnal Ecopsy, 5(3), 130-137. https://doi.org/10.2991/iccie-18.2019.65

Lombogia, B. J., Kairupan, B. H. R., \& Dundu, A. E. (2018). Hubungan Kecanduan Internet dengan Dualitas Tidur Pada Siswa SMA Kristen 1 Tomohon. Jurnal Medik Dan Rehabilitasi (JMR), 1(2), 1-8.

Mareta, H. R., Hardjono, H., \& Agustina, L. S. S. (2020). Dampak Pola Komunikasi Keluarga Laissez-Faire Terhadap Kecanduan Internet Pada Remaja Di kota Surakarta. Jurnal Ilmiah Psikologi, 5(1), 44-53.

Novianty, D. D., Sriati, A., \& Yamin, A. (2019). Gambaran Penggunaan Dan Tingkat Kecanduan Internet Pada Siswa-Siswi Sma X Di Jatinangor. Jurnal Keperawatan Komprehensif, 5(2), 76-87. https://doi.org/10.33755/jkk.v5i2.138

Permana, H., Harahap, F., \& Astuti, B. (2016). Hubungan Antara Efikasi Diri Dengan Kecemasan Dalam Menghadapi Ujian Pada Siswa Kelas IX Di MtS Al Hikmah Brebes. Jurnal Hisbah, 13(1), 51-68. https://doi.org/10.14421/hisbah.2016.132-04

Putro, K. Z. (2017). Memahami Ciri dan Tugas Perkembangan Masa Remaja. Aplikasia: Jurnal Aplikasi Ilmu-Ilmu Agama, 17(1), 25-32. https://doi.org/10.14421/aplikasia.v17i1.1362

Sari, S. P., Aryansah, J. E., \& Sari, K. (2020). Resiliensi Mahasiswa Dalam Menghadapi Pandemi Covid 19 dan Implikasinya Terhadap Proses Pembelajaran. Jurnal Of Guidance and Counseling, 9(1), 17-22. journal.unnes.ac.id/sju/index.php/jbk

Triyono, \& Muh. Ekhsan Rifai. (2018). Efikasi Diri dan Regulasi Emosi dalam Mengatasi Prokrastinasi Akademik (Khunti Pratiwi (ed.)). CV Sindunata.

Wita, M. M. N. A., Khasanah, A. N., \& Rahayu, M. S. (2018). Tipe Parental Mediation dan Adiksi Internet Siswa Kelas V SD X Bandung. Psympathic: Jurnal Ilmiah Psikologi, 5(2), 221-230. https://doi.org/10.15575/psy.v5i2.3310

Wulandari, S. (2019). Perilaku Remaja (Yulianawati (ed.)). Mutiara Aksara.

Yang, S.-Y., \& Kim, H.-S. (2018). Effects Of A Prevention Program For Internet Addiction Among Middle School Students In South Korea. Public Health Nursing, 1-10. https://doi.org/10.1111/phn.12394

Young, K. S., \& Abreu, C. N. de. (2017). Kecanduan Internet (K. S. Young \& C. N. de Abreu (eds.)). Pustaka Belajar.

Young, K. S., \& Rogers, R. C. (1998). The Relationship Between Depression And Internet Addiction. CyberPsychology \& Behavior, 1(1), 25-28. 